\title{
Methylation of free-floating deoxyribonucleic acid fragments in the bronchoalveolar lavage fluid of dogs with chronic bronchitis exposed to environmental tobacco smoke
}

Yoshiki Yamaya ${ }^{1 *}$, Hiroshi Sugiya $^{2}$ and Toshihiro Watari ${ }^{1}$

\begin{abstract}
Background: The etiology of canine chronic bronchitis (CB) is not completely understood, although exposure to environmental tobacco smoke (ETS) affects the airway inflammatory responses in some dogs with CB. The mechanism by which this occurs is unknown.

Findings: We investigated the concentrations and methylation rates of free-floating DNA fragments in bronchoalveolar lavage fluid (BALF) from dogs with chronic bronchitis. Based on serum cotinine levels, dogs with CB were divided into 2 groups: dogs that either had or had not been exposed to ETS. Our results demonstrated that the total nucleated cell and macrophage numbers increased in BALF of ETS-exposed dogs with CB. There were no significant differences in DNA concentrations and methylation rates in BALF between the 2 groups. However, 3 out of 8 dogs exposed to ETS had high DNA methylation rates in their BALF samples.
\end{abstract}

Conclusion: Our results suggest that ETS exposure leads to epigenetic modifications of cellular components in BALF in dogs diagnosed with CB.

Keywords: Chronic bronchitis, DNA methylation, Dog, Second-hand smoke

\section{Findings}

Deoxyribonucleic acid (DNA) methylation is an epigenetic modification that mainly occurs in $\mathrm{CpG}$ dinucleotides in the CpG-rich islands located within gene promoter regions. Methylation of $\mathrm{CpG}$ islands in promoter regions is generally associated with gene silencing. Another epigenetic modification, DNA hypomethylation, is associated with gene transcription [1]. The level of epigenetic DNA methylation is considered to be an important factor in the pathogenesis of various human diseases, including pulmonary diseases such as lung cancer and chronic obstructive pulmonary disease (COPD), a pulmonary disorder associated with exposure to cigarette smoke [2-4]. In humans, tobacco smoke exposure causes changes, such as DNA methylation that are reversible

\footnotetext{
* Correspondence: yamaya.yoshiki@nihon-u.ac.jp

'Laboratory of Comprehensive Veterinary Clinical Studies, Department of Veterinary Medicine, College of Bioresource Sciences, Nihon University, Kameino 1866, Fujisawa, Kanagawa, Japan

Full list of author information is available at the end of the article
}

and DNA mutations that are irreversible, to the epigenetic status [5-10].

In dogs, environmental tobacco smoke exposure (ETS) plays a role in various smoking-related respiratory conditions $[11,12]$. When mice were exposed to ETS, the overall response was primarily global DNA hypomethylation in the lung [13]. This finding is most consistent with our current understanding of ETS-induced carcinogenesis. In contrast, in cultured human airway epithelial cells exposed to ETS, the induction of locoregional DNA hypermethylation in the CpG-rich gene promoter region was observed [14].

The etiology of canine chronic bronchitis $(\mathrm{CB})$ is not completely understood, although ETS exposure has additional effects on the airway inflammatory responses in some dogs with CB [12]. We examined the effect of ETS exposure on airway inflammatory responses. We measured the concentrations and methylation rates of freefloating DNA fragments in the bronchoalveolar lavage 
fluid (BALF) from dogs diagnosed with $\mathrm{CB}$ who had or had not been exposed to ETS. We compared the changes in these parameters between the two groups.

\section{Methods}

Nineteen dogs (4-12 years; 11 males and 8 females) diagnosed with CB were included in this study. Between April 2005 and March 2010, these dogs had been referred to the Animal Medical Center of Nihon University for diagnoses and consultations for long-term therapy for their clinical signs. The breeds included Miniature Dachshund $(\mathrm{n}=12)$, Shih Tzu $(\mathrm{n}=2)$, and 1 each of Pug, Maltese, Papillon, Shetland sheepdog, and mixed breed. CB was diagnosed based on normal ranges of blood test results, thickened bronchial walls on chest $\mathrm{X}$-ray and computed tomography, mucosal secretions, and patterned indented surface in bronchoscopy. Total nucleated cell counts were determined and the results were used, provided the dogs did not present with other nasal, throat, cardiac, infectious and neoplastic diseases. Either an elevated total nucleated cell count $(>=400$ cells $/ \mu \mathrm{L})$ with macrophage dominance $(>=50 \%)$ or normal total nucleated cell count $(<400$ cells $/ \mu \mathrm{L})$ with neutrophil dominance $(>=15 \%)$ in the BALF samples was used as one of the parameters for the inclusion criteria. All examinations were performed after informed consent of the dogs' owners under the guideline for the care and use of laboratory animals by The College of Bioresource Sciences, Nihon University.

Blood samples were collected from jugular veins as in routine clinical examinations. Serum was isolated by centrifugation and stored at $-20^{\circ} \mathrm{C}$ until used for cotinine measurements. Serum cotinine was determined using a Cotinine Passive Smoking ELISA Kit (Cosmic Corporation, Tokyo, Japan). BALF samples from the dogs were obtained by gentle aspiration through a biopsy channel of a bronchoscope after infusing sterile saline $(0.9 \% \mathrm{NaCl})$ solution $(40 \mathrm{~mL}$, divided into 2 aliquots) under general anesthesia with isoflurane. BALF sample supernatants were isolated by centrifugation $(200 \times g$ for $10 \mathrm{~min})$ and immediately stored at $-20^{\circ} \mathrm{C}$ until DNA extraction. Free-floating DNA in $200 \mu \mathrm{L}$ of BALF supernatant was concentrated to $20 \mu \mathrm{L}$ using a DNA Extractor Kit (Wako, Japan). Concentrations of the extracted DNA in sera and BALF samples were determined using a Nanodrop Spectrophotometer (NanoDrop Technologies, USA) and corrected by urea concentrations (QuantiChrom ${ }^{\mathrm{TM}}$ Urea Assay Kit, BioAssay Systems, Hayward, CA, USA).

DNA methylation rates were determined with a Methylamp Global DNA Methylation Quantification Ultra Kit (Epigentek, USA) according to the manufacturer's instructions. The capture antibody in this kit binds to 5-methylcytosine. The total DNA methylation level was determined as a percentage of the total DNA in a given sample. This technique measured the total DNA fragments in the samples but not specific sites, patterns, or methylation types. Samples were run in duplicate and points for the standard curve were run in triplicate.

Medians with the range of minimum and maximum values were used to express results. Group results were compared by the Mann-Whitney rank sum test for nonnormally distributed variables. $\mathrm{P}$ values $<0.05$ were considered significant. All statistical analyses were performed using SigmaPlot for Windows, Version12.0 (Systat Software, Inc., San Jose, CA, USA).

\section{Results}

Based on serum cotinine levels, 19 dogs with CB were divided into 2 groups: dogs who either had or had not been exposed to ETS. Eleven dogs (4-12 years) not exposed to ETS and 8 dogs (6-11 years) exposed to ETS were analyzed. The results from their BALF samples are shown in Table 1. Total nucleated cell counts and the numbers of macrophages in BALF from dogs exposed to ETS were significantly higher than those of the dogs not exposed to ETS. There were no significant differences in DNA concentration $(\mathrm{P}=0.386)$, corrected

\begin{tabular}{|c|c|c|}
\hline & Unexposed dogs & Exposed dogs \\
\hline Number & 11 & 8 \\
\hline Males:Females & $8: 3$ & $3: 5$ \\
\hline Age(y) & $7.2 \pm 2.5$ & $8.6 \pm 2.3$ \\
\hline $\begin{array}{l}\text { Serum cotinine } \\
\text { levels ( } \mathrm{ng} / \mathrm{mL} \text { ) }\end{array}$ & $0(0-0)$ & $0.41(0.03-1.42)^{*}$ \\
\hline \multicolumn{3}{|l|}{ Cells in BALF } \\
\hline $\begin{array}{l}\text { Total nucleated cell } \\
\text { counts (cells/ } \mu \mathrm{L})\end{array}$ & $124(57-231)$ & $600(100-3175)^{*}$ \\
\hline Macrophages (\%), & $56(8-79)$ & $73(50-92)$ \\
\hline (cells/ $/ \mu \mathrm{L}$ ) & $56(9-148)$ & $438(50-2921)^{*}$ \\
\hline Neutrophils (\%), & $21(2-82)$ & $12(0-27)$ \\
\hline (cells/ $\mu \mathrm{L}$ ) & $30(3-178)$ & $26(0-345)$ \\
\hline Lymphocytes (\%), & $19(3-54)$ & $7(0-36)$ \\
\hline 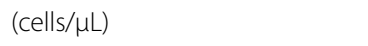 & $24(2-78)$ & $35(0-870)$ \\
\hline Eosinophils (\%), & $0(0-4)$ & $0(0-3)$ \\
\hline (cells/ $\mu \mathrm{L}$ ) & $0(0-4)$ & $0(0-20)$ \\
\hline $\begin{array}{l}\text { Total DNA concentrations } \\
\text { (ng/ } \mathrm{LL})\end{array}$ & $7.0(3.3-20.2)$ & $5.7(2.4-29.4)$ \\
\hline $\begin{array}{l}\text { Corrected DNA concentrations } \\
\text { (ng/ } \mathrm{LL})\end{array}$ & $413(158-1582)$ & $478(112-743)$ \\
\hline Rates of DNA methylation (\%) & $11.4(1.0-23.9)$ & $17.0(9.5-42.7)$ \\
\hline
\end{tabular}

*: significant differences between groups $(p<0.05)$. 
DNA concentration $(P=0.756)$, and DNA methylation $(\mathrm{P}=0.076)$ in the BALF samples. The rate of DNA methylation in 3 of the 8 dogs exposed to ETS was higher than the range of that rate in dogs not exposed to ETS (Table 1).

\section{Discussion}

It has been reported that acute tobacco smoke exposure induced alveolar macrophage apoptosis [15]. If the source of DNA fragments in BALF was alveolar macrophages, it would be expected that the DNA concentrations in BALF would be higher in dogs exposed to ETS than those not exposed to ETS. We found no differences in the DNA concentrations in the BALF samples in either group. In this study, the number of macrophages in dogs exposed to ETS was higher than those in dogs not exposed to ETS. This result is supported by the results from a previous report, where the phagocytic activity of macrophage was enhanced by ETS exposure in both healthy dogs and those with $\mathrm{CB}$ [16].

Damaged airway epithelial cells may also be a considerable source of free-floating DNA in BALF. Gene hypermethylation occurs in the bronchial epithelium of human smokers $[5,10]$. In human patients with COPD, gene methylation was enhanced in the sputum, which includes bronchial secretions with exfoliated cells from the lower respiratory tract [17]. In addition, $20 \%$ of atopic human patients develop asthma, which is usually exacerbated by environmental factors including air pollution or oxidative stress. DNA methylation in airway epithelial cells was reduced in atopic children but increased in asthmatic children with the histopathological response in airway epithelial cells [18]. The enhanced methylation of free-floating DNA fragments in BALF may be linked with the histopathological damage in airway epithelial cells caused by ETS exposure in dogs with CB [12].

The limitations of this study were the small sample size and an unknown source of free-floating DNA fragments in the BALF samples. In addition, there is no available information regarding normal methylation levels of free-floating DNA fragments in BALF from clinically healthy adult dogs. It is possible that DNA levels in BALF samples from healthy dogs may be undetectable or very low. Similar results were found in the airway samples from healthy human subjects [17].

\section{Conclusion}

We conclude that ETS exposure may lead to epigenetic modifications of cellular components in BALF from dogs with $\mathrm{CB}$. Further studies will be needed to determine the location of genes with aberrant methylation patterns and their therapeutic implications in dogs with CB that either have or have not been exposed to ETS. Theophyline and $\beta 2$-adrenergic agonists may be therapeutic and beneficial for normalizing DNA methylation $[2,19]$.

\section{Abbreviations}

BALF: Bronchoalveolar lavage fluid; CB: Chronic bronchitis; DNA: Deoxyribonucleic acid; ETS: Environmental tobacco smoke.

\section{Competing interests}

The authors declare that they have no competing interests.

\section{Authors' contributions}

YY, HS, and TW designed the study. YY and TW examined and diagnosed all subjects through blood test, chest $X$-ray, computed tomography and bronchoscopy. YY and HS analyzed serum cotinine levels and deoxyribonucleic acid concentrations and methylations in bronchoalveolar lavage fluid. All authors read and approved the final manuscript.

\section{Acknowledgements}

We thank Dr. Hajime Shiba, Department of Applied Biological Science, Nihon University, for methodological improvements. This study was supported by a grant from the Smoking Research Foundation.

\section{Author details}

${ }^{1}$ Laboratory of Comprehensive Veterinary Clinical Studies, Department of Veterinary Medicine, College of Bioresource Sciences, Nihon University, Kameino 1866, Fujisawa, Kanagawa, Japan. ${ }^{2}$ Laboratory of Veterinary Biochemistry, Department of Veterinary Medicine, College of Bioresource Sciences, Nihon University, Kameino 1866, Fujisawa, Kanagawa, Japan.

Received: 7 November 2014 Accepted: 25 March 2015

Published online: 29 April 2015

\section{References}

1. Riggs AD, Jones PA. 5-methylcytosine, gene regulation, and cancer. Adv Cancer Res. 1983;40:1-30.

2. Kabesch M, Adcock IM. Epigenetics in asthma and COPD. Biochimie. 2012;94:2231-41.

3. Provinciali M, Cardelli M, Marchegiani F. Inflammation, chronic obstructive pulmonary disease and aging. Curr Opin Pulm Med. 2011;17:S3-10.

4. Talikka M, Sierro N, Ivanov NV, Chaudhary N, Peck MJ, Hoeng J, et al. Genomic impact of cigarette smoke, with application to three smokingrelated diseases. Crit Rev Toxicol. 2012;42:877-89.

5. Belinsky SA, Palmisano WA, Gilliland FD, Crooks LA, Divine KK, Winters SA, et al. Aberrant promoter methylation in bronchial epithelium and sputum from current and former smokers. Cancer Res. 2002;62:2370-7.

6. Breitling LP, Yang R, Korn B, Burwinkel B, Brenner H. Tobacco- smokingrelated differential DNA methylation: $27 \mathrm{~K}$ discovery and replication. Am J Hum Genet. 2011;88:450-7.

7. Destro A, Bianchi P, Alloisio M, Laghi L, Di Gioia S, Malesci A, et al. K-ras and p16 (INK4A) alterations in sputum of NSCLC patients and in heavy asymptomatic chronic smokers. Lung Cancer. 2004;44:23-32.

8. Hillemacher T, Frieling H, Moskau S, Muschler MA, Semmler A, Kornhuber J, et al. Global DNA methylation is influenced by smoking behaviour. Eur Neuropsychopharmacol. 2008;18:295-8.

9. Soria JC, Rodriguez M, Liu DD, Lee JJ, Hong WK, Mao L. Aberrant promoter methylation of multiple genes in bronchial brush samples from former cigarette smokers. Cancer Res. 2002;62:351-5.

10. Zöchbauer-Müller S, Lam S, Toyooka S, Virmani AK, Toyooka KO, Seidl S, et al. Aberrant methylation of multiple genes in the upper aerodigestive tract epithelium of heavy smokers. Int J Cancer. 2003;107:612-6.

11. Reif JS, Dunn K, Ogilvie GK, Harris CK. Passive smoking and canine lung cancer risk. Am J Epidemiol. 1992;135:234-9.

12. Hawkins EC, Clay LD, Bradley JM, Davidian M. Demographic and historical findings, including exposure to environmental tobacco smoke, in dogs with chronic cough. J Vet Intern Med. 2010;24:825-31.

13. Tommasi S, Zheng A, Yoon Jl, Li AX, Wu X, Besaratinia A. Whole DNA methylome profiling in mice exposed to secondhand smoke. Epigenetics. 2012;7:1302-14.

14. Liu F, Killian JK, Yang M, Walker RL, Hong JA, Zhang M, et al. Epigenomic alterations and gene expression profiles in respiratory epithelia exposed to cigarette smoke condensate. Oncogene. 2010;29:3650-64. 
15. Aoshiba K, Tamaoki J, Nagai A. Acute cigarette smoke exposure induces apoptosis of alveolar macrophages. Am J Physiol Lung Cell Mol Physiol. 2001;281:L1392-401

16. Roza MR, Viegas CA. The dog as a passive smoker: effects of exposure to environmental cigarette smoke on domestic dogs. Nicotine Tob Res. 2007;9:1171-6.

17. Guzmán L, Depix MS, Salinas AM, Roldán R, Aguayo F, Silva A, et al. Analysis of aberrant methylation on promoter sequences of tumor suppressor genes and total DNA in sputum samples: a promising tool for early detection of COPD and lung cancer in smokers. Diagn Pathol. 2012;7:87.

18. Stefanowicz D, Hackett TL, Garmaroudi FS, Günther OP, Neumann S, Sutanto EN, et al. DNA methylation profiles of airway epithelial cells and PBMCs from healthy, atopic and asthmatic children. PLoS One. 2012;7:e44213.

19. Moens U, Subramaniam N J Johansen B, Aarbakke J. The c-fos CAMPresponse element: regulation of gene expression by a beta 2-adrenergic agonist, serum and DNA methylation. Biochim Biophys Acta. 1993;1173:63-70.

\section{Submit your next manuscript to BioMed Central and take full advantage of:}

- Convenient online submission

- Thorough peer review

- No space constraints or color figure charges

- Immediate publication on acceptance

- Inclusion in PubMed, CAS, Scopus and Google Scholar

- Research which is freely available for redistribution 